\title{
Meta
}

Journal des traducteurs

Translators' Journal

\section{Encouraging the Use of E-mail and Mailing Lists Among Translation Students}

\section{Amparo Alcina-Caudet}

Volume 48, numéro 4, décembre 2003

URI : https://id.erudit.org/iderudit/008745ar

DOI : https://doi.org/10.7202/008745ar

Aller au sommaire du numéro

\section{Éditeur(s)}

Les Presses de l'Université de Montréal

\section{ISSN}

0026-0452 (imprimé)

1492-1421 (numérique)

Découvrir la revue

\section{Citer cette note}

Alcina-Caudet, A. (2003). Encouraging the Use of E-mail and Mailing Lists Among Translation Students. Meta, 48(4), 634-641.

https://doi.org/10.7202/008745ar

\section{Résumé de l'article}

La fréquence d'usage des ressources informatiques est un facteur clef pour que l'étudiant acquière les habiletés qui concernent les nouvelles technologies. Il faut dessiner des stratégies destinées à encourager l'autonomie des étudiants et à fournir des ressources appropriées pour les inciter à accéder aux outils informatiques hors de l'horaire des classes. Dans le but de promouvoir l'usage du courrier électronique ainsi que la familiarisation des étudiants en traduction avec les listes de diffusion, on a créé la liste de diffusion INFOTRAD. Cet article présente les caractéristiques principales de cette liste, comment on l'a créée et les résultats obtenus pendant les premiers mois de fonctionnement. 


\title{
BLOC-NOTES
}

\author{
Encouraging the Use of E-mail and Mailing Lists \\ Among Translation Students'
}

\begin{abstract}
RÉSUMÉ
La fréquence d'usage des ressources informatiques est un facteur clef pour que l'étudiant acquière les habiletés qui concernent les nouvelles technologies. Il faut dessiner des stratégies destinées à encourager l'autonomie des étudiants et à fournir des ressources appropriées pour les inciter à accéder aux outils informatiques hors de l'horaire des classes. Dans le but de promouvoir l'usage du courrier électronique ainsi que la familiarisation des étudiants en traduction avec les listes de diffusion, on a créé la liste de diffusion INFOTRAD. Cet article présente les caractéristiques principales de cette liste, comment on l'a créée et les résultats obtenus pendant les premiers mois de fonctionnement.
\end{abstract}

\begin{abstract}
How often students use IT resources is a key factor in the acquisition of skills associated to the new technologies. Strategies aimed at increasing student autonomy need to be developed and should offer resources that encourage them to make use of computing tools outside class hours. The mailing list INFOTRAD was created with the aim of encouraging the use of e-mail and of familiarising students of Translation and Interpreting with mailing lists. In this paper, we look at the chief characteristics of this list, how it came into being and the results obtained during its first six months in operation.
\end{abstract}

\section{MOTS-CLÉS/KEYWORDS}

teaching, computing for translation, e-mail, mailing list, INFOTRAD

\section{Introduction $^{2}$}

The use of the Internet as a means of communication is becoming more and more widespread as the number of people who take advantage of the services it offers grows day after day. Translation is undoubtedly one of the professions that has benefited most from this new system (Sager 1994; Badia et al. 1999; Rico Pérez 2001). Electronic mail, or e-mail, makes it easier to send and receive texts and to communicate with customers, who may be anywhere in the world. It also enables translators to subscribe to mailing lists, where they can exchange information about the profession with other translators, resolve doubts about terminology (Depecker 1997), seek out material on a particular subject, offer work to other translators, and so on.

It is important, therefore, that translation students should have sufficient knowledge of how these Internet services work and of the software needed to use them. On the one hand, this will help them when they move into the job market and, on the other, it will enable them to go on learning, clear up doubts and, one day, contribute with their knowledge and experience (Skinner 1998).

\section{Training translation students in the use of the new technologies}

In the theoretical classes and practical sessions held in the translation laboratory that make up the subject "Computing for Translation," students are taught how to use and practise using the software applications that help a translator work more efficiently (Borja Albi et al. 1998). But this knowledge is quickly forgotten if it does not go hand in hand with a continued use outside the classroom or the teaching lab. However, on many occasions the student finds no reason to make use of these tools outside teaching hours.

Any student feels motivated to open a browser on the Internet because they know that on some website or other they will find information about the sport they practise, about their favourite singer, about grants that enable them to study abroad, and so on. And yet the motivation to use an e-mail application varies quite a lot from one student to another. This is because they will only choose it as a means of communication if the people they want to get in touch with have access to an e-mail account and it is convenient for them to use.

Therefore, it seems advisable to draw up learning strategies that motivate the student to use these services and offer resources that help develop autonomy in the use of these tools. In this case, a mailing list was created as a teaching aid for use outside the classroom. 


\section{Mailing lists as a teaching aid}

A mailing list is a service that is offered through the Internet and which allows electronic messages to be sent and received between people who share an interest in a particular topic.

Messages are written, sent and received using any of the e-mail applications available on the market (Eudora, Netscape Messenger, Outlook, Mail, Pine, etc.).

Anyone interested in receiving the messages from a particular list first has to send a message to the administrator applying for subscription. Once they have been accepted onto the list, they can pick up the messages sent to their electronic mailbox by the other members. They can also send their own messages to the e-mail address provided by the list and from there they are sent on to all the other people who have subscribed to it.

Mailing lists are, then, an excellent way of practising how to use e-mail. Students no longer depend on whether their friends have got an e-mail address or not, or whether they send messages or not. By subscribing to one or several lists, they ensure that they will get at least some new e-mail every day.

There are many mailing lists on the subject of languages and translation on the Internet (see Annex). However, over the period of a few years, during which the main features and functions of mailing lists were explained to students and they were encouraged to take part in them, it was also found that they were not appealing to students. Subject matters in the mailing lists are becoming so specialised and their members such experts within their profession that students often have difficulty in following the discussions in the forum or in making any contribution with their messages. In addition to this, many lists have restricted access and only admit people who can prove they have a professional interest in the subject the list is about, which leads to a feeling of frustration at not being able to connect to some of them.

Taking all the above into consideration, it was decided that the best thing to do would be to start up a list that would be especially appealing to students of Translation and Interpreting at the UJI. In this way, the idea to create INFOTRAD was born.

\section{The INFOTRAD mailing list}

The INFOTRAD list was created with the aim of encouraging the use of e-mail applications and mailing lists among students of Translation and Interpreting. To do so, the subject matter of the list had to respond to the interests of these particular students so that they would feel motivated to use e-mail on a regular basis. Since one of the main concerns students have when they finish their degree is looking for a job, it seemed that the idea of creating a mailing list where they could find job offers for people with a degree in Translation and Interpreting would be of interest to them.

We will now go on to describe the technical aspects of its creation and details about how it was started up and how it works.

\subsection{Technical aspects of the creation and maintenance of the list}

A mailing list is yet another of the services that can be offered by an Internet server, like websites, e-mail or file transfer. Portals, virtual communities or servers belonging to public organisation offer users the possibility of creating and maintaining mailing lists, in which case they become the moderator or owner of the list. Basically what happens is that these entities make some space on the server computer available to the owner of the list and provide a password so that the different options can be configured. The list is managed by a software application (such as Listserv or Majordomo) that automatically performs the administrative processes that will allow users to subscribe or remove their name from the list, as well as controlling the different options concerning the receiving of messages.

In our case, we used the form that appears at the following website, <http://sic.uji.es/serveis/si/ correu/llistes/instancia.html $>$, to apply to Universitat Jaume I Computing Service for permission to create the list. Information required by the form includes the name of the person who will be the owner of the list, a name and description of the subject matter the messages must fit and a series of options regarding the kind of list to be created.

First of all, the description was given as "A mailing list to provide information about job offers and about meetings, conferences and courses associated to translating, interpreting, terminology and the application of new technologies to translation."

Secondly, we had to choose between the following options:

1) Open/restricted:

We chose to leave it open. In this way, students who ask to sign up are added to the list automatically without needing the owner's authorisation. When the list is restricted, the owner must give his or her consent every time someone applies to sign up. This seemed rather unnecessary in this case. 
2) Moderated/unmoderated:

It was decided that the list should be UNMODERATED. Students who join can send messages to the list and they are automatically distributed by the system. If the MODERATED option is chosen, each message has to receive prior authorisation from the owner before it is forwarded to the members of the list.

3) Allow / Do not allow non-members to take part in the list

We decided to use the "allow" option. In this way, anyone could send messages to the list without having to join. This makes it easier for any lecturer, member of the University administrative staff or company to send job offers or information about courses or anything else that might be of interest to students. Thus, the flow of information within the list is promoted while at the same time preventing people from having their mailboxes invaded by offers they are not interested in receiving.

4) Public / private

If the list is public, its existence is made known through the University website, which means that it is accessible to everyone. Since the list deals with a very specific subject aimed at translation students, we decided not to make it public, at least at first while we checked on whether it was operating properly.

After we had submitted the completed form, the computing service created the list and provided the password required to manage it.

\subsection{Subscribing to the list}

Once the list had been created and configured, students were given the electronic addresses they needed to subscribe to the INFOTRAD list and to send messages.

Although the software that manages the list allows a group of electronic addresses to subscribe automatically and the electronic addresses of students enrolled at the university can easily be obtained from the directory available through the e-ujier system operated by Universitat Jaume I, it was seen as being important that students carry out their own subscription. In this way, they would become familiarised with the process they should follow when they want to sign up to other lists or even if they should wish to subscribe to INFOTRAD again using another electronic address.

During the practical sessions carried out in class, students were asked to subscribe to the list and to send a message to their companions informing them of some event they knew about. Messages were also sent to students from other courses and to former students who had already obtained their degree inviting them to subscribe to the list.

To subscribe to the INFOTRAD list, a message should be sent to $<$ majordomo@llistes.uji.es $>$ with just the words subscribe infotrad as the body of the message. There is no need to write anything as the subject of the message nor sign it (Figure 1). The system automatically and instantaneously adds the sender's address to the list.

\section{FIGURE 1 \\ Subscription to the INFOTRAD list}

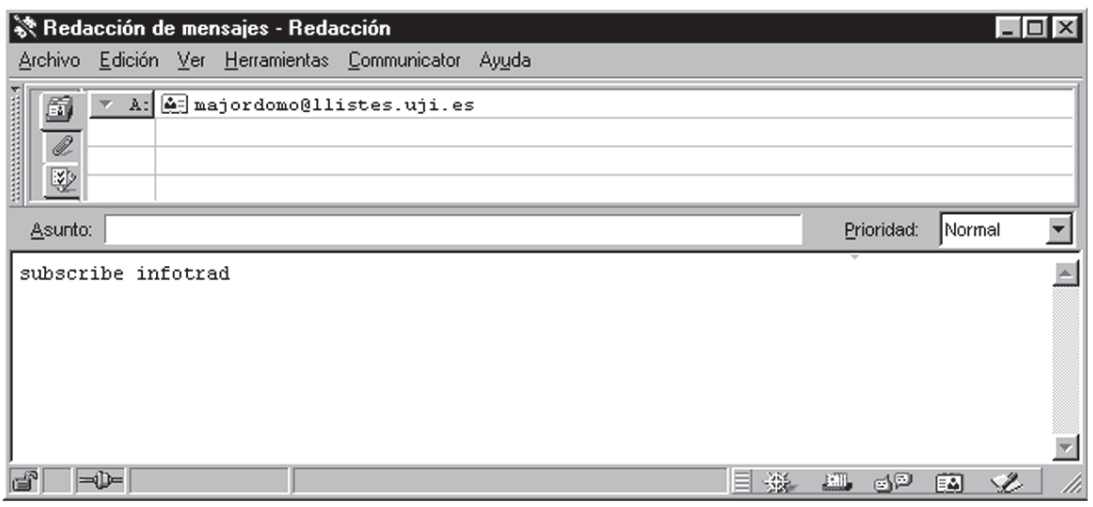

In order to pass news on to the members of the list, a message has to be written and sent to <infotrad@llistes.uji.es> (Figure 2). 
FIGURE 2

\section{Sending a message to INFOTRAD}

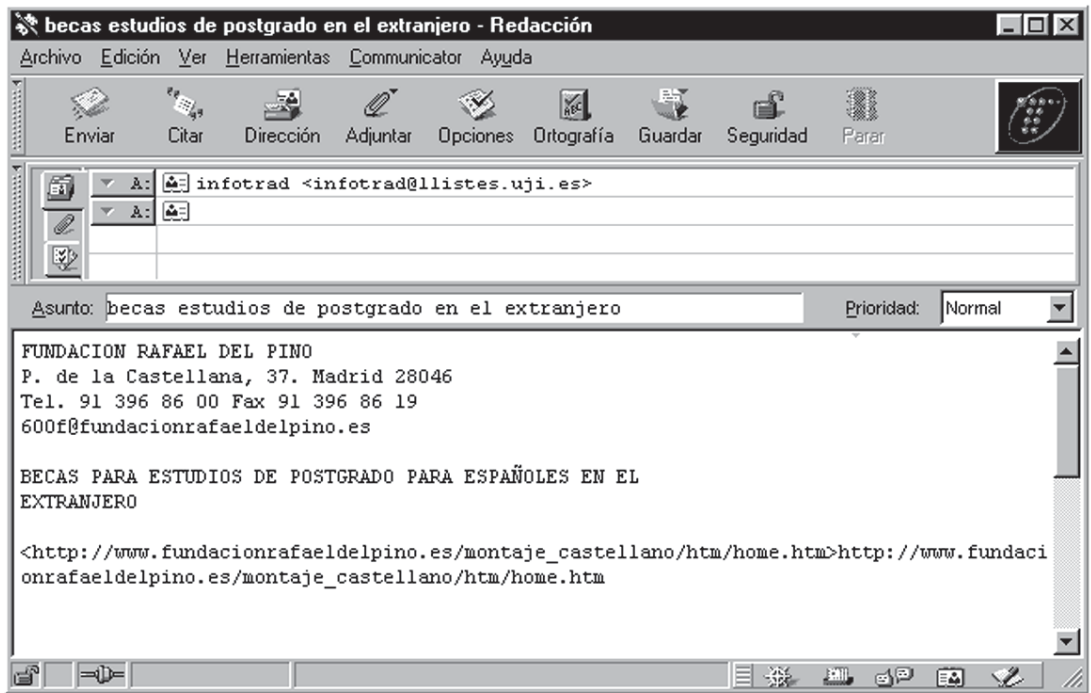

Once students have sent their messages to the list, they can retrieve the messages that have been sent through the list from their mailbox. The INFOTRAD list was designed in such a way that the system automatically adds the word [INFOTRAD] to the subject of the sender's original message. This allows students to know that it was sent through INFOTRAD before actually opening it (Figure 3 ).

FIGURE 3

\section{Inbox Folder}

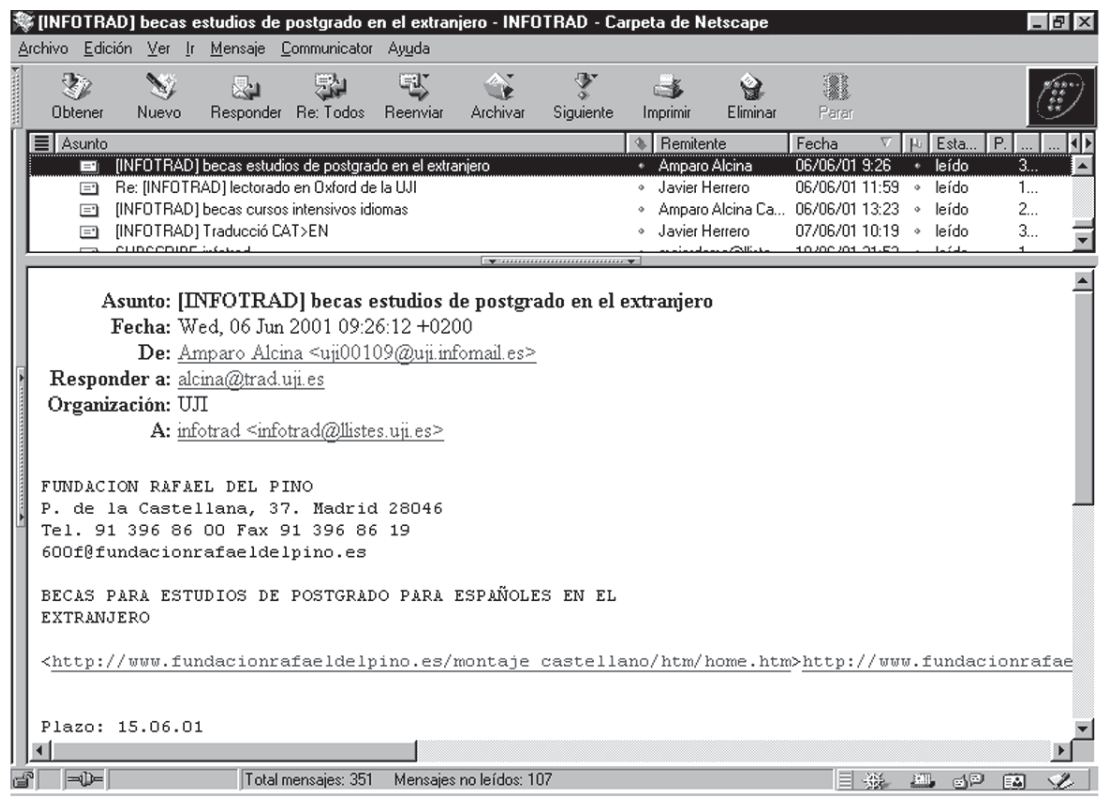


The following piece of text is also added at the end of the message:

INFOTRAD. A mailing list to provide information about job offers and about meetings, conferences and courses associated to translating, interpreting, terminology and the application of new technologies to translation.

To send a message to all the subscribers to the list, in the space provided for the address, write: <infotrad@llistes.uji.es>

In order to subscribe, cancel a subscription or other options, you should send the appropriate command to this address: <majordomo @llistes.uji.es> (The main Majordomo commands can be consulted at the following website: $<$ http://sic.uji.es/serveis/si/correu/llistes/index.html $>$ ).

This note at the end of each message reminds users of the subject matter of the list, as well as the electronic addresses that should be used to send their messages and configure the way they receive their messages.

While the appearance of the expression [INFOTRAD] in the subject of the message allows users to know where it comes from before opening the message, it also makes it easier for the e-mail application to sort messages automatically. To do so, users should create a folder in their incoming mailbox (called INFOTRAD, for example) and configure a filter so that messages received through the list are automatically put into that folder (Figure 4).

FIGURE 4

Filter configuration

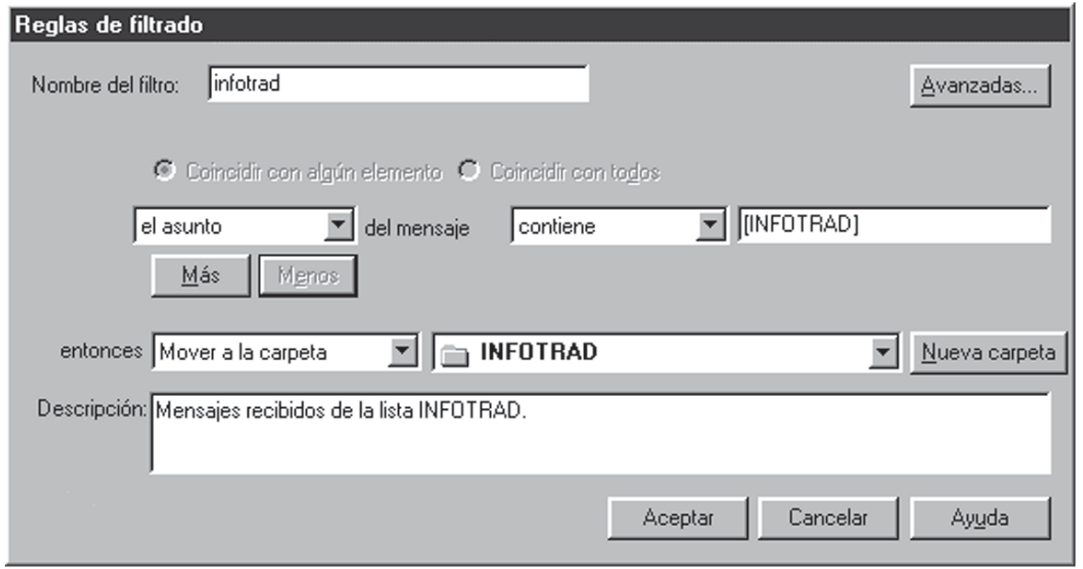

Having set up this filter, all the messages from INFOTRAD are stored in the INFOTRAD folder when they are downloaded from the server (Figure 5). 
FIGURE 5

INFOTRAD folder

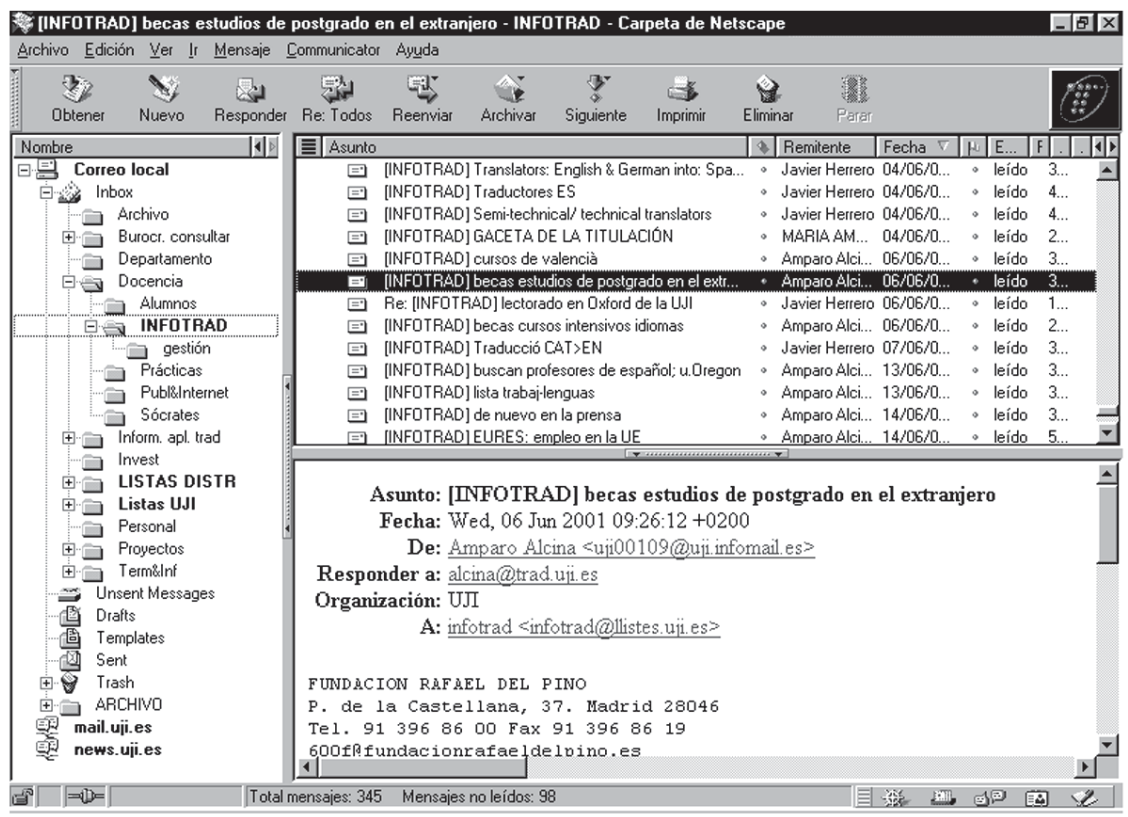

\subsection{Supplying the list with messages}

Once the list has been created and students have been invited to join it, it becomes necessary to ensure it receives a continuous supply of messages. To begin with, supplying the INFOTRAD list was achieved by forwarding offers that appeared in other lists the owner was subscribing to, together with some adverts from the press.

Some time later, a postgraduate associate scholarship holder from the Department of Translation and Communication was incorporated into the project and entrusted with the task of looking for adverts in the press and writing out the messages for the list. Lecturers within the department were told the address where they could send any messages with interesting offers they might know of.

The active collaboration of lecturers from the department, who had not joined the list but did send in the offers they received, meant that some messages were repeated - something that caused some inconvenience to students. This problem was solved by having all offers first sorted by the associate scholarship holder. Thus, offers of interest to students that had been received by lecturers were passed on to this collaborator, who only posted those that were not already on the list.

When a new list devoted to offering jobs of interest to professionals working in Spanish - Trabajlenguas - appeared in April, the same procedure was used and students were informed of its existence and encouraged to join it. They were also warned that the offers appearing on this list would not be forwarded to INFOTRAD in order to prevent messages from being duplicated.

\section{Appraisal of the results and conclusions}

Between November 2000, when the list was created, and June 2001, 104 students and former students of Translation and Interpreting at Universitat Jaume I, some of whom were overseas students who had enrolled in the Computing for Translation course, had subscribed to the list.

The list has received and posted an average of 33 messages a month, with the lowest figure being 28 in March and the highest occurring in May, with 52. All messages were suited to the subject matter of the list.

A survey was carried out among students to find out how satisfied they felt with this project and look into whether our aims had been reached or not. The survey was sent through the list and students had to send them back to the administrator. Twenty correctly completed forms were received, i.e. $20.8 \%$ 
of the users answered the questionnaire. All them considered taking part in the list to be a satisfying experience. There had also been a significant increase in how often e-mail was used and the number of students that had joined other lists had tripled.

However, their role as suppliers of messages was practically non existent. This situation might change if the aims of the list are expanded and students are encouraged to exchange information about references, terminology or interesting texts they come across while translating for other courses. Yet, when they were asked if it seemed a good idea to use the list to consult other students, there was a fairly wide range of opinions. One comment that did appear quite often was that another list should be created to deal with this kind of information exchange, keeping INFOTRAD for job and course offers.

To sum up, our aim of encouraging students to use e-mail and mailing lists in and outside class hours has been successfully achieved, while at the same time we have also managed to provide students with a number of job offers available to translators and interpreters.

In view of the results obtained after its first year in operation, it would seem to be worthwhile making the mailing list accessible to more people. The most suitable way of doing so would be to create a subscription form on a website. Finally, in answer to students' suggestions, another list will be created to enable users to exchange terminological information, documentary references and sources, and comments on translations.

Amparo Alcina-Caudet

Universitat Jaume I, Castelló, Spain alcina@trad.uji.es

\section{NOTES}

1. Text translated by Mark Andrews and revised by the Language and Terminology Service at Universitat Jaume I.

2. This research was funded by Fundació Caixa Castelló (P1A98-12 and P1.1A2000-02) and the Generalitat Valenciana (GV00-143-9 and GV00-155-09). I would like to thank Antonio García, Javier Herrero and Marta Renau for their collaboration in creating, maintaining and assessing the INFOTRAD list.

\section{REFERENCES}

Badia, T., K. H. Freigang, J. Haller, C. Horschmann, D. Huber, B. Maia, U. Reuther and P. Schmidt (1999): LETRAC Curriculum Modules.

Borja Albi, A., S. Gamero Pérez and J. C. Ruiz Antón (1998): “El laboratorio de traducción como escenario didáctico," Quaderns. Revista de traducció, 2, pp. 143-154.

Depecker, L. (1997): “L’Internet: un médium qui bouleverse les contenus linguistiques," Français dans le Monde, numéro spécial-juillet, pp. 165-182.

Rico Pérez, C. (2001): "From Novelty to Ubiquity: Computers and Translation at the Close of the Industrial Age," Translation Journal, 5-1.

SAGer, J. C. (1994): Language Engineering and Translation. Consequences of Automation, vol. 1, Amsterdam/ Philadelphia: John Benjamins, Benjamins Translation Library.

Skinner, W. (1998): “New Technologies and the Translation Classroom,” Jerome Quarterly, 13-2, Nov-Dec, pp. 3-5.

\section{ANNEXES}

1. Some mailing lists related to translation and language

- Español Urgente. List of debates on the Spanish language organised by the Spanish news agency EFE. Further information can be found at: http://www.el-castellano.com/foros.html

- Infoling. Topics related to Spanish linguistics: above all, projects and doctoral theses, sponsored research projects, courses, seminars and talks, publications (books, journals, etc.). Further information can be found at: http://www.rediris.es/list/info/infoling.es.html

- Minerva. Literary Translation. Further information can be found at: http://www.rediris.es/list/info/ minerva.es.html

- TecnoTrad. The technology that can be used as aids in translating. Further information can be found at: http://www.rediris.es/list/info/tecnotrad.es.html

- Termilat. Terminology, language industries and related activities in Romance languages. Further information can be found at: http://www.unilat.org/dtil/termilat/presentacion.htm

- Trabaj-lenguas. Job opportunities of interest to professionals working with the Spanish language. Job offers posted include translation work, advertisements for vacancies for teachers in public or private institutions, scholarships, places for students on doctoral courses, calls to apply for job positions, vocational training contracts, addresses of websites, mail lists and any organisation or body where there are job offers for those who work in Spanish. Further information at: http://www.eListas.net/lista/trabaj-lenguas 
- Traducción. Translation in Spain. Further information can be found at: http://www.rediris.es/list/info/ traduccion.es.html

- Tradumática. The new technologies applied to translating, i.e. automatic and assisted translation, information retrieval and management, exploiting terminological databases, along with everything related to the introduction of IT in translating, in terminology and in documentation. Further information can be found at: http://www.rediris.es/list/info/tradumatica.es.html

- Tradux. Forum for enquiries about terminology for translators working to and from English and Spanish. Further information can be found at: http://www.egroups.com/group/tradux

2. Servers providing list creation services

- Rediris. Further information: http://www.rediris.es/list/poli.es.html

- $\quad$ E-listas. Further information: http://www.eListas.net/ 8 